obtained from the oxidized fibres. The principles underlying the use of tetrakis (hydroxymethyl) phosphonium chloride in flame-proofing wool have been examined, and it has been found that presence of this substance enhances the ability of fibres to take a set in aqueous media.

In the Department of Colour Chemistry and Dyoing there were 48 undergraduate students in the eightieth (1958-59) and 45 in the eighty-first (1959 60) session, with 17 and 23, respectively, working for higher degrees. A study of the influence of the acetyl value of acetate rayon on the rate of dyeing and affinity of disperse dyes was completed. Work continued on the kinetic and thermodynamic aspects of the dyeing of acetate rayon with sulphated dyes and on the influence of the chemical constitution of non-ionic azo dyes on their affinity for cellulose. Other work has been concerned with the effect of benzyl alcohol and $n$-butyl alcohol on the absorption by wool of dyes containing metal and the chemistry of ketones related to mesobenzanthrone, particularly their behaviour towards substituting agents and their ability to undergo self-union in alkaline media with formation of vat dyes. An investigation of the status of sulphinic acids as substituting agents yielded some interesting and potentially useful sulphones and some new reactions, and provided an explanation of the course of several applications of sulphinic acids in organic chemistry. Work was completed on derivatives of 2-methylanthraquinone and 2-alkylquinizarins and the influence of the chemical constitution of non-ionic azo dyes on their affinity for cellulose. Lists of publications during the year are included in both reports.

\title{
THE BRITISH LEATHER MANUFACTURERS' RESEARCH ASSOCIATION
}

T THE annual report of the British Leather Manufacturers' Research Association for the year October 1960-September 1961 *, includes the reports of the Council and of the Director of Research, the latter including a list of publications, together with details of membership of the Council, its committees and of staff. Renewed attention was given to the problem of finding new outlets for leather and emphasis was placed in a report to the Council on the overwhelming importance of using the raw hides and skins to the best advantage.

The Director's report outlines the programme of research for 1961-62 and notes some features of the current year's work. In background research, work on the composition of skin proteins centred on the separation of collagenous and non-collagenous protein in acetic acid extracts of calf-skin. Investigations of the mechanical and elastic properties of collagen and leather have been extended to combinationtanned fibres, both semichrome and chrome re-tan. In studying the deterioration of leather by heat, moisture and perspiration it has been shown that exposure to dry heat or to high humidities at normal temperatures eauses little deterioration and that it is the combined action of heat and moisture which is deleterious, involving breakdown of polypeptide chains both by hydrolysis and an oxidative process involving loss of amino-acids.

* British Leather Manufacturers' Research Association. Annual Report, 1960-61. Pp. 58. (Egham: Surrey: British Leather Manufacturers' Research Association, 1961.)
Experiments in which sheep-skins were deliberately allowed to stale before using have shown that while staling reduced the quality of the skins, as judged by thinness, pits and holes and also the strength of the leather, it did not appear to lower rot-resistance. Examination of the effect of adding antiseptics to the salt used for curing sheep-skins indicated that processes within the control of the fellmonger or tanner have at least as big an effect. Progress in reducing the cost of unhairing by enzymes is reported through the demonstration that the enzyme liquor can be re-used several times. It has also been found that salt concentrations of 10 per cent or more reduce enzyme activity in de-woolling sheep-skins and a 2 per cent solution of enzyme is just as effective as a 20 per cent solution.

Other work has been concerned with control of the thickness of vegetable-tanned sole leather, vegetable tan sludges, laminated leathers and solvent-assisted dyeing, in which a technique was developed for topping suèdes by spraying by emulsifying in wator a solution of the pigment dyestuff in benzyl alcohol. More recently, anionic dyestuffs have been dissolved in a single-phase solvent system of water, isopropyl alcohol and benzyl alcohol and sprayed direct on to the leather. Work has been started on new impregnating finishes for upper leather and considerable progress made in waterproofing chrome upper leather with silicones. The outstanding problem remaining is to improve the retention of silicones by the leather over long periods of use.

\section{NEW DIRECTIONS IN PETROLEUM EXPLORATION, PRODUCTION AND TRANSPORTATION} W WITING in the November-December $1961_{\text {issue of the Battelle Technical Review published }}$ by the Battelle Memorial Institute, Columbus, Ohio, Dr. Frank C. Croxton propounds some novel, if not revolutionary, ideas for explorations of oil-pools, techniques for crude-oil production and transportation.
In the field of exploration location of future oil deposits envisages extensive use of gas surveys, microbiological indicators, radio-geochemical methods and advanced electronic instruments. The aim is development and use of geophysical methods of greater sensitivity and portability, thus utilizing more direct methods of oil-finding, especially in "vast 